\title{
Magnesium Deficiency Alters Expression of Genes Critical for Muscle Magnesium Homeostasis and Physiology in Mice
}

\author{
Dominique Bayle ${ }^{1}$, Cécile Coudy-Gandilhon ${ }^{1}$, Marine Gueugneau ${ }^{1}$, Sara Castiglioni ${ }^{2}{ }^{(0)}$, Monica Zocchi ${ }^{2}{ }^{\circ}$, \\ Magdalena Maj-Zurawska ${ }^{3,4}{ }^{1}$, Adriana Palinska-Saadi ${ }^{3,4}$, André Mazur ${ }^{1}$, Daniel Béchet ${ }^{1, *}$ \\ and Jeanette A. Maier ${ }^{2,5}$ \\ 1 UNH, Unité de Nutrition Humaine, Université Clermont Auvergne, INRAE, \\ F-63000 Clermont-Ferrand, France; dominique.bayle@inrae.fr (D.B.); \\ cecile.coudy-gandilhon@inrae.fr (C.C.-G.); marine.gueugneau@inrae.fr (M.G.); andre.mazur@inrae.fr (A.M.) \\ 2 Department of Biomedical and Clinical Sciences Luigi Sacco, Università di Milano, 20157 Milano, Italy; \\ sara.castiglioni@unimi.it (S.C.); monica.zocchi@unimi.it (M.Z.); jeanette.maier@unimi.it (J.A.M.) \\ 3 Biological and Chemical Research Centre, University of Warsaw, PL-02-089 Warsaw, Poland; \\ mmajzur@chem.uw.edu.pl (M.M.-Z.); adusp@cnbc.uw.edu.pl (A.P.-S.) \\ 4 Faculty of Chemistry, University of Warsaw, PL-02-093 Warsaw, Poland \\ 5 Interdisciplinary Centre for Nanostructured Materials and Interfaces (CIMaINa), Università di Milano, \\ 20133 Milano, Italy \\ * Correspondence: daniel.bechet@inrae.fr
}

check for updates

Citation: Bayle, D.; Coudy-Gandilhon, C.; Gueugneau, M.; Castiglioni, S.; Zocchi, M.; Maj-Zurawska, M.; Palinska-Saadi, A.; Mazur, A.; Béchet, D.; Maier, J.A. Magnesium Deficiency Alters Expression of Genes Critical for Muscle Magnesium Homeostasis and Physiology in Mice. Nutrients 2021, 13, 2169. https://doi.org/10.3390/ nu13072169

Academic Editors: Roberto Iacone and Lindsay Brown

Received: 8 May 2021

Accepted: 22 June 2021

Published: 24 June 2021

Publisher's Note: MDPI stays neutral with regard to jurisdictional claims in published maps and institutional affiliations.

Copyright: (c) 2021 by the authors. Licensee MDPI, Basel, Switzerland. This article is an open access article distributed under the terms and conditions of the Creative Commons Attribution (CC BY) license (https:/ / creativecommons.org/licenses/by/ $4.0 /)$.
Abstract: Chronic $\mathrm{Mg}^{2+}$ deficiency is the underlying cause of a broad range of health dysfunctions. As $25 \%$ of body $\mathrm{Mg}^{2+}$ is located in the skeletal muscle, $\mathrm{Mg}^{2+}$ transport and homeostasis systems (MgTHs) in the muscle are critical for whole-body $\mathrm{Mg}^{2+}$ homeostasis. In the present study, we assessed whether $\mathrm{Mg}^{2+}$ deficiency alters muscle fiber characteristics and major pathways regulating muscle physiology. C57BL/6J mice received either a control, mildly, or severely $\mathrm{Mg}^{2+}$-deficient $\operatorname{diet}\left(0.1 \% ; 0.01 \%\right.$; and $0.003 \% \mathrm{Mg}^{2+} \mathrm{wt} / \mathrm{wt}$, respectively) for 14 days. $\mathrm{Mg}^{2+}$ deficiency slightly decreased body weight gain and muscle $\mathrm{Mg}^{2+}$ concentrations but was not associated with detectable variations in gastrocnemius muscle weight, fiber morphometry, and capillarization. Nonetheless, muscles exhibited decreased expression of several MgTHs (MagT1, CNNM2, CNNM4, and TRPM6). Moreover, TaqMan low-density array (TLDA) analyses further revealed that, before the emergence of major muscle dysfunctions, even a mild $\mathrm{Mg}^{2+}$ deficiency was sufficient to alter the expression of genes critical for muscle physiology, including energy metabolism, muscle regeneration, proteostasis, mitochondrial dynamics, and excitation-contraction coupling.

Keywords: skeletal muscle; magnesium; magnesium transporters; transcriptome

\section{Introduction}

Magnesium $\left(\mathrm{Mg}^{2+}\right)$ intake is suboptimal in the population of Western countries, which results in an increased risk of latent $\mathrm{Mg}^{2+}$ deficiency with Western diet behavior [1]. In addition, there is an increased risk of low $\mathrm{Mg}^{2+}$ status in the elderly and after several current pharmacological treatments, such as proton pump inhibitors, thiazides, cetuximab, cisplatin, and some antibiotics [2,3]. In hospitalized patients, hypomagnesemia is a frequent finding often associated with other electrolyte disorders [4]. Clinical manifestations, depending on the severity and chronicity of deficiency, include a large variety of symptoms, e.g., neuromuscular symptoms (hyperexcitability, tetany, cramps, fasciculation, tremor, spasms, weakness), fatigue, tachycardia, anorexia, apathy, and behavioral alterations. In comparison to severe acute $\mathrm{Mg}^{2+}$ deficiency, the diagnosis of chronic latent $\mathrm{Mg}^{2+}$ deficiency is difficult, because magnesemia is often within reference intervals and results in nonspecific clinical symptoms [5,6]. However, it is well recognized that chronic $\mathrm{Mg}^{2+} \mathrm{defi}^{-}$ ciency contributes to a broad range of metabolic, cardiovascular, immune, and neurological disorders [7]. 
$\mathrm{Mg}^{2+}$ is the second (after $\mathrm{K}^{+}$) most abundant intracellular cation and $\mathrm{Mg}^{2+}$ is critical for a number of biological processes. $\mathrm{Mg}^{2+}$ is a natural $\mathrm{Ca}^{2+}$ antagonist, the activator of more than 200 enzymes, and the direct cofactor of over 600 enzymes [7]. In addition, intracellular $\mathrm{Mg}^{2+}$ is buffered by many biological molecules, including proteins, RNAs, DNA, and ATP. ATP is mainly bound to $\mathrm{Mg}^{2+}$, and $\mathrm{MgATP}^{2-}$ is the active species in enzyme binding and energy production. Therefore, the intracellular concentration of $\mathrm{Mg}^{2+}$ must be tightly regulated. This is achieved through the activity of $\mathrm{Mg}^{2+}$ permeable channels and transporters. The last few years have seen rapid progress in the identification and characterization of $\mathrm{Mg}^{2+}$ transport and homeostasis systems (MgTHs), including transient receptor potential cation channel subfamily M member 6 (TRPM6) and 7 (TRPM7), magnesium transporter 1 (MagT1), magnesium transporter MRS2, solute carrier family 41 member 1 (Slc41a1) and 3 (Slc41a3), cyclin, CBS domain divalent metal cation transport mediator 1 (CNNM1) and 4 (CNNM4) [7-9]. Although the precise function of MgTHs is still under investigation, current knowledge suggests that cellular $\mathrm{Mg}^{2+}$ homeostasis is regulated by the combined action of several ubiquitous $\mathrm{Mg}^{2+}$ transporters.

Besides its role in energy production, in the skeletal muscle $\mathrm{Mg}^{2+}$ controls contraction by acting as a $\mathrm{Ca}^{2+}$ antagonist on $\mathrm{Ca}^{2+}$-permeable channels and $\mathrm{Ca}^{2+}$-binding proteins. Accordingly, $\mathrm{Mg}^{2+}$ deficiency decreases muscle strength [10]. Moreover, aging, frequently associated with low $\mathrm{Mg}^{2+}$ status, is characterized by the gradual decline of muscle mass and performance. About $25 \%$ of body $\mathrm{Mg}^{2+}$ is located in the skeletal muscle, which indicates that the expression of MgTHs is relevant to whole-body $\mathrm{Mg}^{2+}$ homeostasis. Gene and/or protein expression of ubiquitous $\mathrm{MgTH}$ s have been demonstrated in the skeletal muscle (http:/ /www.proteinatlas.org/ accessed on 10 April 2021), but their specific functions in this tissue have not been elucidated. Moreover, to our knowledge, few studies on the regulation of MgTHs in skeletal muscle under pathophysiological conditions, including $\mathrm{Mg}^{2+}$ status, have been published [11].

We were interested in unveiling the early events occurring in the skeletal muscle in response to a low $\mathrm{Mg}^{2+}$-containing diet. The principal aim of this study was to individuate whether and how a short-term $\mathrm{Mg}^{2+}$-deficient diet modulates muscle fiber characteristics and cellular pathways critical for muscle physiology.

\section{Materials and Methods}

\subsection{Animals}

The present study (APAFIS\#14025-201803121538803) was approved by the Ethics Committee C2EA-02 and was conducted in accordance with the National Research Council Guide for the Care and Use of Laboratory Animals. All animals were maintained in a temperature-controlled room $\left(22 \pm 1^{\circ} \mathrm{C}\right)$ with a 12:12 h light:dark cycle and handled according to the recommendations of the Institutional Ethics Committee. Two-monthold male C57BL $/ 6 \mathrm{~J}$ mice were housed for one week in a standard environment with a control diet $\left(0.1 \% \mathrm{Mg}^{2+} \mathrm{wt} / \mathrm{wt}\right)$. The mice were then randomly divided into three groups, and over the following two weeks, each group $(n=12)$ was fed one of the three following diets: control diet $\left(0.1 \% \mathrm{Mg}^{2+} \mathrm{wt} / \mathrm{wt}\right)$, mildly $\mathrm{Mg}^{2+}$-deficient diet $\left(0.01 \% \mathrm{Mg}^{2+} \mathrm{wt} / \mathrm{wt}\right)$, or severely $\mathrm{Mg}^{2+}$-deficient diet $\left(0.003 \% \mathrm{Mg}^{2+} \mathrm{wt} / \mathrm{wt}\right)$. The $\mathrm{Ca}^{2+}$ content of the diets was $0.4 \%$ (wt/wt). All diets were prepared in our laboratory. Distilled water and food were available ad libitum. Quantitative magnetic resonance of live mice was carried out to estimate body fat and lean mass using an EcoMRI-100 analyzer (Echo Medical Systems LLC, Houston, TX, USA). At the end of the experiment, the animals were sacrificed, blood was collected from the heart in heparin-containing tubes, and gastrocnemius muscles were excised. Plasma was obtained by centrifugation ( $10 \mathrm{~min}, 3500 \mathrm{rpm}, 4^{\circ} \mathrm{C}$ ) and frozen for later analysis. Muscles were weighed and (i) maintained in RNAlater (Qiagen, Courtaboeuf, France) overnight at $4{ }^{\circ} \mathrm{C}$ before extracting RNA, (ii) frozen in isopentane cooled on liquid $\mathrm{N}_{2}$ and stored at $-80{ }^{\circ} \mathrm{C}$ for histology, or (iii) snap-frozen in liquid $\mathrm{N}_{2}$ for muscle $\mathrm{Mg}^{2+}$ measurements. 


\section{2. $\mathrm{Mg}^{2+}$ Analysis}

Plasma magnesium was quantified using a Magnesium Calgamite kit according to the manufacturer's instructions (Biolabo, Maizy, France). Erythrocytes were washed 3 times with a saline solution, hemolyzed in water, and centrifuged. Muscle samples were mineralized in $65 \% \mathrm{HNO}_{3}$ for $48 \mathrm{~h}$, and then $1.5 \mathrm{~mL}$ of deionized $\mathrm{H}_{2} \mathrm{O}$ and $0.8 \mathrm{~mL}$ of $18 \mathrm{~mol} / \mathrm{L} \mathrm{NaOH}$ were added. Magnesium analyses were performed on a chemistry analyzer (Indiko Plus, Thermo Fisher Scientific, Vantaa, Finland).

\subsection{Fiber Morphometry and Capillary Network}

Serial cross sections (10 $\mu \mathrm{m}$ thick) were obtained using a cryostat (Microm, Francheville, France) at $-25^{\circ} \mathrm{C}$. Myofiber morphometry and capillarization were assessed on cross sections after labeling with anti-laminin- $\alpha 1$ (Sigma, Saint-Quentin-Fallavier, France) and anti-CD31 (M0823 from Dako, Glostrup, Denmark), respectively, and capturing images by a BX-51 microscope (Olympus, Rungis, France) according to [12,13]. On average, $710 \pm 48$ fibers were analyzed per subject. Fiber cross-sectional area (CSA) and perimeter were determined for each fiber, using the image processing software Visilog-6.9 (Noesis, Gif-sur-Yvette, France) as previously described [12]. A shape factor (perimeter ${ }^{2} / 4 \pi$ CSA) was calculated, with a value of 1.0 indicating a circle and $>1.0$ an increasingly elongated ellipse. A mean of $229 \pm 13$ capillaries was analyzed per subject. Capillary density (CD) was expressed as the number of capillaries counted per square $\mathrm{mm}$. Capillary-to-fiber ratio $(\mathrm{C} / \mathrm{F})$ was calculated as the ratio between the number of capillaries and the number of fibers present in the same area [13].

\subsection{Quantitative Real-Time Polymerase Chain Reaction ( $q R T-P C R$ ) Analysis}

Independent RNA isolations were carried out for each gastrocnemius muscle sample. Total RNAs were extracted using the RNeasy Fibrous Tissue Mini Kit (Qiagen) following the manufacturer's conditions. RNA concentrations were measured using a NanoDrop ND-1000 (LabTech, Ringmer, UK), and RNA quality was verified by $1 \%$ agarose gel electrophoresis. One $\mu \mathrm{g}$ total RNA was used as a template for single-strand cDNA synthesis using High-Capacity cDNA RT Kit (Applied Biosystems, Foster City, CA, USA) in a total volume of $20 \mu \mathrm{L}$ containing 1 X RT buffer, $4 \mathrm{mM}$ dNTP mix, 1 X random primers, $50 \mathrm{U}$ reverse transcriptase and $20 \mathrm{U}$ RNase inhibitor. The primer sequence is reported in Table 1. The reverse transcription reactions were run as follows: $25^{\circ} \mathrm{C}$ for $10 \mathrm{~min}, 37^{\circ} \mathrm{C}$ for $120 \mathrm{~min}$, and $85{ }^{\circ} \mathrm{C}$ for $5 \mathrm{~s}$. PCR was carried out in a final volume of $20 \mu \mathrm{L}$ containing $10 \mu \mathrm{L}$ Power SYBR Green PCR Master Mix (Applied Biosystems), $0.4 \mu \mathrm{L}$ of each primer at $10 \mathrm{pmol} / \mu \mathrm{L}$, and $2 \mu \mathrm{L}$ of the cDNA solution. qRT-PCR amplification was performed using a CFX96 Real-Time PCR Detection System (Bio-Rad, Marnes-la-Coquette, France) with the following thermal cycler conditions: $15 \mathrm{~min}$ at $95^{\circ} \mathrm{C}$, followed by 45 cycles of $15 \mathrm{~s}$ at $95^{\circ} \mathrm{C}$, and $1 \mathrm{~min}$ at $60^{\circ} \mathrm{C}$. Raw data were analyzed using CFX Maestro (Bio-Rad) and compared by the $\Delta \Delta \mathrm{Ct}$ method. Results are expressed relative to the housekeeping gene $(A c t b)$ transcript quantity.

\subsection{TaqMan Low-Density Array (TLDA)}

A total of $500 \mathrm{ng}(10 \mu \mathrm{L})$ cDNA of each sample was combined with $95 \mu \mathrm{L}$ of nucleasefree water and $105 \mu \mathrm{L} 2$ X TaqMan ${ }^{\mathrm{TM}}$ Fast Advanced Master Mix (Applied Biosystems) for the quantitative real-time PCR (qPCR) measurements. This mixture was divided equally over two sample-loading ports of the TLDA. The arrays were centrifuged once ( $1 \mathrm{~min}$, $1300 \mathrm{rpm}$ at room temperature) to equally distribute the sample over the wells. Subsequently, the card was sealed to prevent exchange between wells. qPCR amplification was performed using an Applied Biosystems 7900HT system with the following thermal cycler conditions: $2 \mathrm{~min}$ at $50{ }^{\circ} \mathrm{C}$ and $10 \mathrm{~min}$ at $94.5^{\circ} \mathrm{C}$, followed by 40 cycles of $30 \mathrm{~s}$ at $97^{\circ} \mathrm{C}$ and $30 \mathrm{~s}$ at $59.7^{\circ} \mathrm{C}$. Raw data were analyzed using Sequence Detection System (SDS) Software v2.4 (Applied Biosystems). The expression of $\beta$-actin (Actb), $\beta$-glucuronidase (Gusb), and hypoxanthine phosphoribosyltransferase (Hprt) were used as controls. The genes analyzed are reported in Table 2. 
Table 1. Sequence of primers used for qRT-PCR.

\begin{tabular}{ccc}
\hline Primers & Forward & Reverse \\
\hline TRPM6 & GACAGTCTAAGCACCTTTTC & AAGCTTGTACCCTTCAGTAG \\
\hline MagT1 & GATGGGCTTTTGCAGCTTTGT & GCAATACACATCATCCTTCGCT \\
\hline SRs2 $41 a 1$ & GGTGATGTGCTCCGGTTTAGA & TGGCCTGGAGTGCTAACTCAT \\
\hline Slc41a2 & TACTGGCCCTACTCCTTCTCC & GGGACTCAATCACTACCACCTC \\
\hline Slc41a3 & CTTCAGCAAGAGATCAGAGCC & CCAGCATAGTCATCGTACTTGG \\
\hline CNNM1 & CTCAGCCTTGAGTTCCGCTTT & GCAGGATAGGTATGGCGACC \\
\hline CNNM3 & GTAGGGTCACAACCTACATC & CATGACATACACAGAAGAGG \\
\hline CNNM4 & AAGTGGCCCACCGTGAAAG & CGCTTCTACTTCTGTTGCTAGG \\
\hline
\end{tabular}

Table 2. Gene analyzed.

\begin{tabular}{|c|c|c|c|}
\hline Acvr $2 a$ & Activin A Receptor Type 2a & Map1lc3b & $\begin{array}{l}\text { Microtubule-Associated Protein } 1 \text { Light Chain } \\
\text { 3 Beta }\end{array}$ \\
\hline Acvr2b & Activin A Receptor Type $2 b$ & $M d m 2$ & Mouse double minute 2 homolog \\
\hline Asb2 & Ankyrin Repeat And SOCS Box Containing 2 & $\operatorname{Mef} 2 c$ & Myocyte Enhancer Factor 2C \\
\hline Atf4 & Activating Transcription Factor 4 & $M f n 1$ & Mitofusin 1 \\
\hline Atg10 & Autophagy Related 10 & Mfn2 & Mitofusin 2 \\
\hline Atg12 & Autophagy Related 12 & Mief1 & Mitochondrial Elongation Factor 1 \\
\hline $\operatorname{Atg} 16 l 1$ & Autophagy Related 16 Like 1 & Mstn & Myostatin \\
\hline Atg3 & Autophagy Related 3 & Myf5 & Myogenic Factor 5 \\
\hline $\operatorname{Atg} 5$ & Autophagy Related 5 & Myod & Myogenic Differentiation 1 \\
\hline $\operatorname{Atg} 7$ & Autophagy Related 7 & Myog & Myogenin \\
\hline Atp2a1 & $\begin{array}{l}\text { ATPase Sarcoplasmic/Endoplasmic Reticulum } \\
\qquad \mathrm{Ca}^{2+} \text { Transporting } 1\end{array}$ & Nbr1 & NBR1 Autophagy Cargo Receptor \\
\hline Becn1 & Beclin 1 & Nrf1 & Nuclear Respiratory Factor 1 \\
\hline Bnip3 & BCL2/adenovirus E1B Interacting Protein 3 & Opa1 & Mitochondrial dynamin like GTPase \\
\hline Capn1 & Calpain 1 & Park2 & Parkin RBR E3 Ubiquitin Protein Ligase \\
\hline Capn2 & Calpain 2 & $P i k 3 c 3$ & $\begin{array}{l}\text { Phosphatidylinositol 3-Kinase Catalytic } \\
\text { Subunit Type } 3\end{array}$ \\
\hline Capn3 & Calpain 3 & Pink1 & PTEN Induced Kinase 1 \\
\hline Casq1 & Calsequestrin 1 & Plin2 & Perilipin 2 \\
\hline$C d k n 1 a$ & Cyclin Dependent Kinase Inhibitor 1A & Plin5 & Perilipin 5 \\
\hline Chac1 & $\begin{array}{c}\text { Glutathione-specific } \\
\text { gamma-glutamylcyclotransferase } 1\end{array}$ & Ppargc1a & $\begin{array}{c}\text { Peroxisome Proliferative Activated Receptor } \\
\text { Gamma Coactivator } 1 \text { Alpha }\end{array}$ \\
\hline CNNM2 & $\begin{array}{c}\text { Cyclin and CBS Domain Divalent Metal Cation } \\
\text { Transport Mediator } 2\end{array}$ & Rhot1 & Ras Homolog Family Member T1 \\
\hline CNNM4 & $\begin{array}{c}\text { Cyclin and CBS Domain Divalent Metal Cation } \\
\text { Transport Mediator } 4\end{array}$ & Ryr1 & Ryanodine Receptor 1 \\
\hline $\operatorname{Cox} 1$ & $\begin{array}{c}\text { Mitochondrially Encoded Cytochrome C } \\
\text { Oxidase I }\end{array}$ & Slc27a1 & Solute Carrier Family 27 Member 1 \\
\hline Creb1 & CAMP Responsive Element Binding Protein 1 & Slc2a1 & Solute Carrier Family 2 Member 1 \\
\hline
\end{tabular}


Table 2. Cont.

\begin{tabular}{|c|c|c|c|}
\hline Cs & citrate synthase & Slc $2 a 4$ & Solute Carrier Family 2 Member 4 \\
\hline Ctsl & Cathepsin L & Slc6a8 & Solute Carrier Family 6 Member 8 \\
\hline Ddit3 & DNA Damage Inducible Transcript 3 & Slc41a1 & Solute Carrier family 41 member 1 \\
\hline Dnm1l & Dynamin 1 Like & Sqstm1 & Sequestosome 1 \\
\hline Eif $4 e b p 1$ & $\begin{array}{c}\text { Eukaryotic Translation Initiation Factor 4E } \\
\text { Binding Protein } 1\end{array}$ & Srebf1 & $\begin{array}{l}\text { Sterol Regulatory Element Binding } \\
\text { Transcription Factor } 1\end{array}$ \\
\hline Fabp3 & Fatty Acid Binding Protein 3 & Srebf 2 & $\begin{array}{l}\text { Sterol Regulatory Element Binding } \\
\text { Transcription Factor } 2\end{array}$ \\
\hline$F b x o 21$ & F-Box Protein 21 & Srl & Sarcalumenin \\
\hline Fbxo30 & F-Box Protein 30 & Tfam & Transcription Factor A, Mitochondrial \\
\hline Fbxo31 & F-Box Protein 31 & Trim63 & Tripartite Motif-containing 63 \\
\hline Fbxo32 & F-Box Protein 32 & Trim72 & Tripartite Motif-containing 72 \\
\hline Fis1 & Fission, Mitochondrial 1 & TRPM6 & $\begin{array}{l}\text { Transient Receptor Potential cation channel } \\
\text { subfamily M member } 6\end{array}$ \\
\hline Foxo3 & Forkhead Box O3 & Ube2b & Ubiquitin Conjugating Enzyme E2 B \\
\hline Fst & Follistatin & Ube2e1 & Ubiquitin-Conjugating Enzyme E2 E1 \\
\hline Fundc1 & FUN14 Domain Containing 1 & Ube2g1 & Ubiquitin-Conjugating Enzyme E2G 1 \\
\hline Gabarapl1v & $\begin{array}{c}\text { Gamma-Aminobutyric Acid A } \\
\text { Receptor-Associated Protein-Like } 1\end{array}$ & Ube $2 j 1$ & Ubiquitin-Conjugating Enzyme E2J 1 \\
\hline Gadd $45 a$ & $\begin{array}{l}\text { Growth Arrest and DNA Damage } \\
\text { Inducible Alpha }\end{array}$ & Ube $2 j 2$ & Ubiquitin-Conjugating Enzyme E2J 2 \\
\hline Gapdh & Glyceraldehyde-3-Phosphate Dehydrogenase & Ube2l3 & Ubiquitin-Conjugating Enzyme E2L 3 \\
\hline Lamp2 & Lysosomal-Associated Membrane Protein 2 & Ulk1 & Unc-51 Like Autophagy Activating Kinase 1 \\
\hline MagT1 & Magnesium Transporter 1 & Zeb1 & Zinc Finger E-Box Binding Homeobox 1 \\
\hline
\end{tabular}

\subsection{Western Blot}

Gastrocnemius muscles were mechanically shredded in a Potter homogenizer with lysis buffer (50 mM Tris- $\mathrm{HCl}$ pH 7.4, 150 mM NaCl, 1\% NP-40, 0.25\% Na-deoxycholate) containing protease inhibitors. Total proteins were quantified using the Bradford reagent (Sigma-Aldrich, St. Louis, MO, USA). Equal amounts of proteins were separated by SDSPAGE on 4-20\% Mini-PROTEAN TGX Stain-free Gels (Bio-Rad, Hercules, CA, USA) and transferred to nitrocellulose membranes by using Trans-Blot ${ }^{\circledR}$ TurboTM Transfer Pack (Bio-Rad). After blocking with bovine serum albumin (BSA), Western blot analysis was performed using primary antibodies against Myog, Opa1 (BD Biosciences, St. Diego, CA, USA), Gapdh, and Mfn2 (Santa-Cruz Biotechnology, Dallas, TX, USA). The filters were washed and incubated with secondary antibodies conjugated to horseradish peroxidase (Amersham Pharmacia Biotech Italia, Cologno Monzese, Italy) were used. The immunoreactive proteins were detected with ClarityTM Western ECL substrate (Bio-Rad) and images were captured with a ChemiDoc MP Imaging System (Bio-Rad). The nitrocellulose sheets were used as control loading. Densitometry of the bands was performed with the software ImageLab (Bio-Rad). The Western blots shown are representative and the densitometric analysis was performed on three independent experiments.

\subsection{Statistical Analysis}

Data are presented as means \pm SE. To determine whether or not data sets were normally distributed, the Shapiro-Wilk and Kolmogorov-Smirnov normality tests were performed. When data were normally distributed, statistical comparisons between groups were performed applying either Student's $t$ test or one-way ANOVA, followed by a Tukey's 
post hoc test, as appropriate. Mann-Whitney U tests were performed when data in at least one group were not normally distributed. Correction for multiple testing was performed with $\mathrm{R}$ according to [14], and TLDA significance was set at q-value $<0.05$. Univariate linear Pearson's regression was carried out to investigate relationships between MgTHs mRNA levels and body weight gain. Statistical analyses were performed using XLSTAT (Addinsoft, Paris, France), and significance was set at $P<0.05$.

\section{Results}

\section{1. $\mathrm{Mg}^{2+}$-Deficient Diet Reduces Muscle $\mathrm{Mg}^{2+}$ Concentrations but Does Not Affect Fiber Characteristics}

To investigate the modulation of the expression of $\mathrm{Mg}^{2+}$ transport and homeostasis systems (MgTHs) in response to $\mathrm{Mg}^{2+}$ status, we used a model of C57BL/6J mice receiving a mildly or severely $\mathrm{Mg}^{2+}$-deficient diet and compared it to mice under an $\mathrm{Mg}^{2+}$-sufficient diet $[15,16]$. After 14 days of diet, mice fed a mildly or severely $\mathrm{Mg}^{2+}$-deficient diet exhibited a $26 \%$ and $75 \%$ reduction in plasma $\mathrm{Mg}^{2+}$ concentration, respectively (Figure 1a). However, no significant change in erythrocyte $\mathrm{Mg}^{2+}$ concentration was detected (Figure $\mathrm{1b}$ ). In parallel, moderate and severe $\mathrm{Mg}^{2+}$ deficiencies resulted in a $4.8 \%$ and $5.4 \%$ decrease in intramuscular $\mathrm{Mg}^{2+}$ concentrations, respectively, compared to the control $\mathrm{Mg}^{2+}$-sufficient diet (Figure 1c).

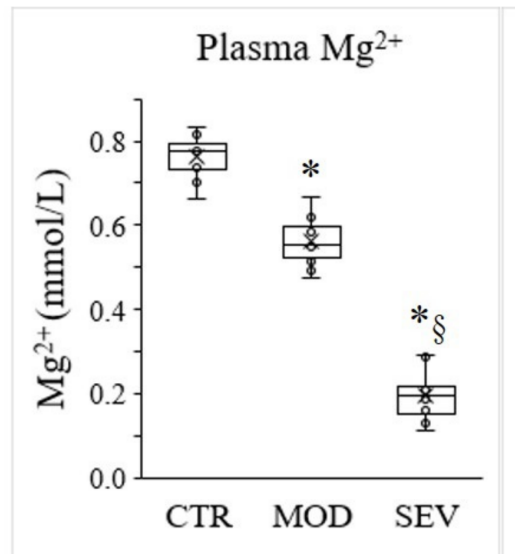

(a)

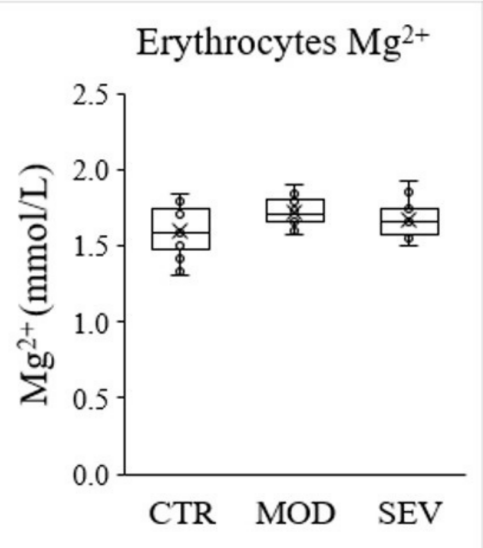

(b)

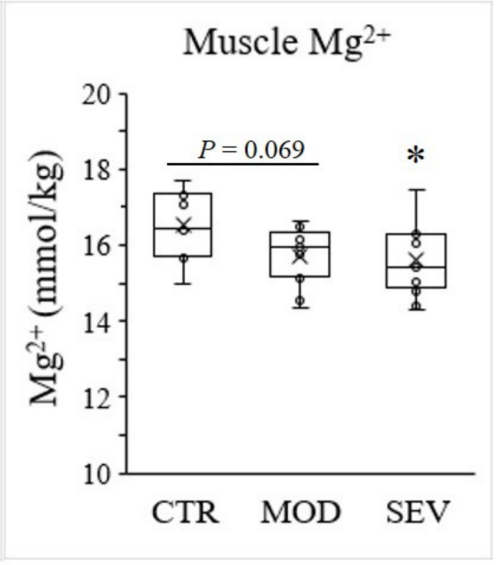

(c)

Figure 1. $\mathrm{Mg}^{2+}$ status in mice. $\mathrm{Mg}^{2+}$ concentrations were measured in (a) plasma, (b) erythrocytes, and (c) gastrocnemius muscle of mice fed either a control (CTR), a mildly (MOD), or a severely (SEV) $\mathrm{Mg}^{2+}$-deficient diet. Data ( $\mathrm{N}=12$ per group) are presented as box-and-whisker plots (centerline, median; box limits, first and third quartiles; whiskers, $1.5 \mathrm{x}$ interquartile range; points, outliers; $x$ in the box, mean). * Significant difference $(P<0.05)$ from the CTR group. $\S$ Significant difference $(P<0.05)$ from the MOD group.

Moderate and severe $\mathrm{Mg}^{2+}$ deficiencies were associated with a significant decline in body weight gain (Figure 2a), and magnetic resonance imaging (EchoMRI) indicated modest trends for whole-body fat and lean mass reductions (Figure 2b,c). Nonetheless, gastrocnemius muscle weight did not differ between $\mathrm{Mg}^{2+}$-deficient and $\mathrm{Mg}^{2+}$-sufficient diets (Figure 3a). Semiquantitative histology further indicated that $\mathrm{Mg}^{2+}$ deficiency was not associated with a detectable variation in muscle fiber cross-sectional area, shape, capillary density (CD), or capillary-to-fiber ratio (C/F) (Figure 3b-d). 


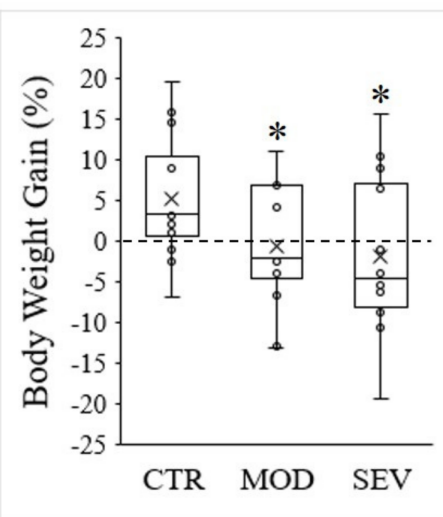

(a)

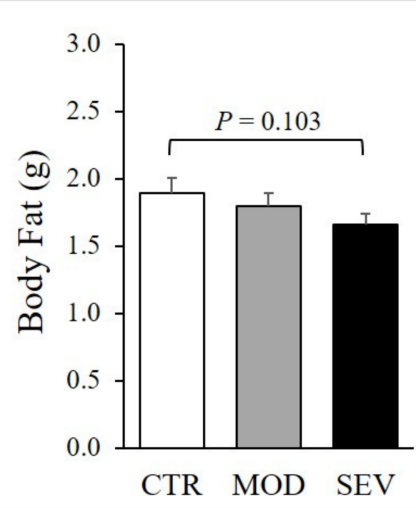

(b)

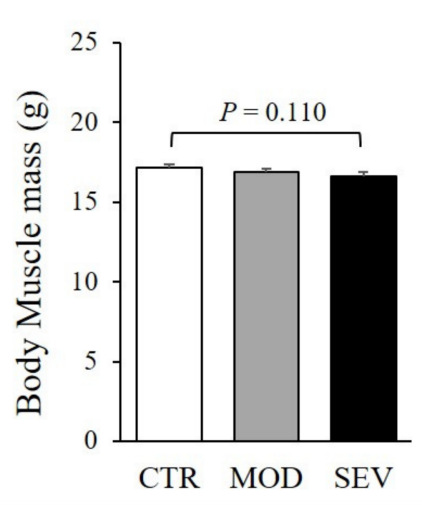

(c)

Figure 2. Body composition of mice fed $\mathrm{Mg}^{2+}$-deficient diet. Mice were fed either a control (CTR), a mildly (MOD), or a severely (SEV) $\mathrm{Mg}^{2+}$-deficient diet: (a) body weight, data $(\mathrm{N}=12)$ presented as box-and-whisker plots, $(\mathbf{b})$ body fat, and (c) body muscle mass were determined by EcoMRI; results are means + SE $(\mathrm{N}=12)$ * Significant difference $(P<0.05)$ from the CTR group.

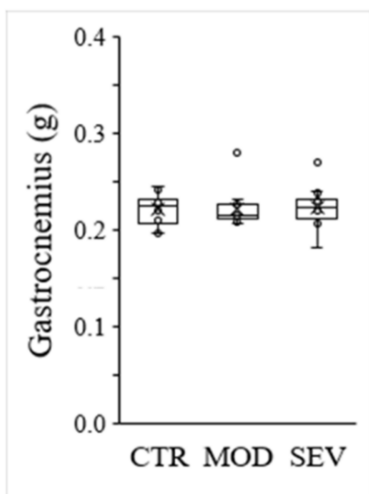

(a)

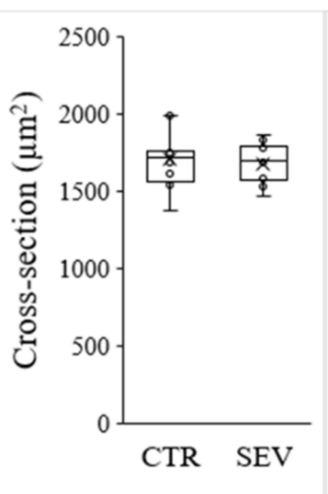

(b)

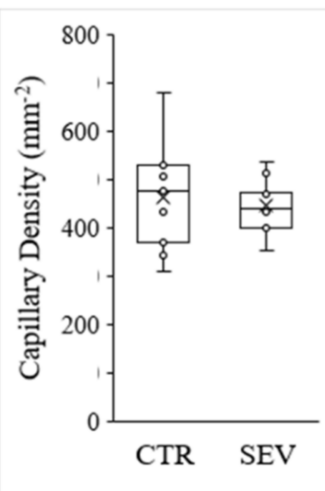

(c)

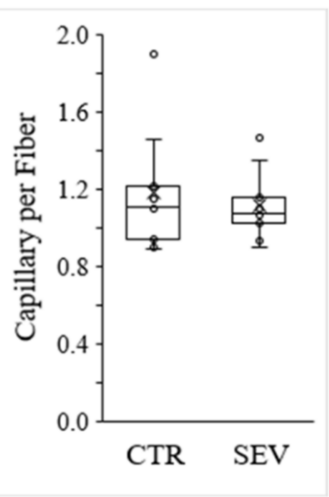

(d)

Figure 3. $\mathrm{Mg}^{2+}$-deficient diet and muscle characteristics. Mice were fed either a control (CTR), a mildly (MOD), or a severely (SEV) $\mathrm{Mg}^{2+}$-deficient diet: (a) gastrocnemius muscle weight; (b) muscle fiber cross-sectional area; (c) muscle capillary density; (d) number of capillaries per fiber. Data $(\mathrm{N}=12$ per group) are presented as box-and-whisker plots.

\section{2. $\mathrm{Mg}^{2+}$-Deficient Diet Alters Expression of Muscle MgTHs}

Although no evidence emerged in terms of atrophy or altered morphology or capillarization of muscle fibers, modest declines in muscular $\mathrm{Mg}^{2+}$ concentrations might nonetheless modulate specific mechanisms to maintain cellular $\mathrm{Mg}^{2+}$ homeostasis. We assessed whether $\mathrm{Mg}^{2+}$ deficiency could be associated with differential expression of MgTHs. qRT-PCR analyses performed on gastrocnemius muscle revealed significant declines in MagT1, CNNM2, CNNM4, and TRPM6 mRNAs in mice under $\mathrm{Mg}^{2+}$-deficient diets, compared to $\mathrm{Mg}^{2+}$-sufficient diets (Figure 4a). MagT1 is a controversial protein initially isolated as a critical mediator of $\mathrm{Mg}^{2+}$ homeostasis in eukaryotes [17] and then as an integral part of the $N$-linked glycosylation complex [18]. As MagT1 mutations associate with hypomagnesemia, we included MagT1 in the list of MgTHs. The mRNA levels of the other MgTHs, i.e., CNNM1, CNNM3, MRS2, Slc41a1, Slc41a2, and Slc41a3, were not altered by $\mathrm{Mg}^{2+}$ deficiency.

Interestingly, regression analyses performed with all mice indicated positive correlation between body weight gain and several MgTHs mRNAs, i.e., $\operatorname{MagT1}(\mathrm{r}=0.35, P=0.038)$, CNNM2 ( $\mathrm{r}=0.38, P=0.022)$, CNNM3 $(\mathrm{r}=0.40, P=0.015)$, CNNM4 $(\mathrm{r}=0.48, P=0.003)$, MRS2 $(r=0.45, P=0.006)$, Slc41a1 $(r=0.50, P=0.002)$ (Figure $4 b)$. 


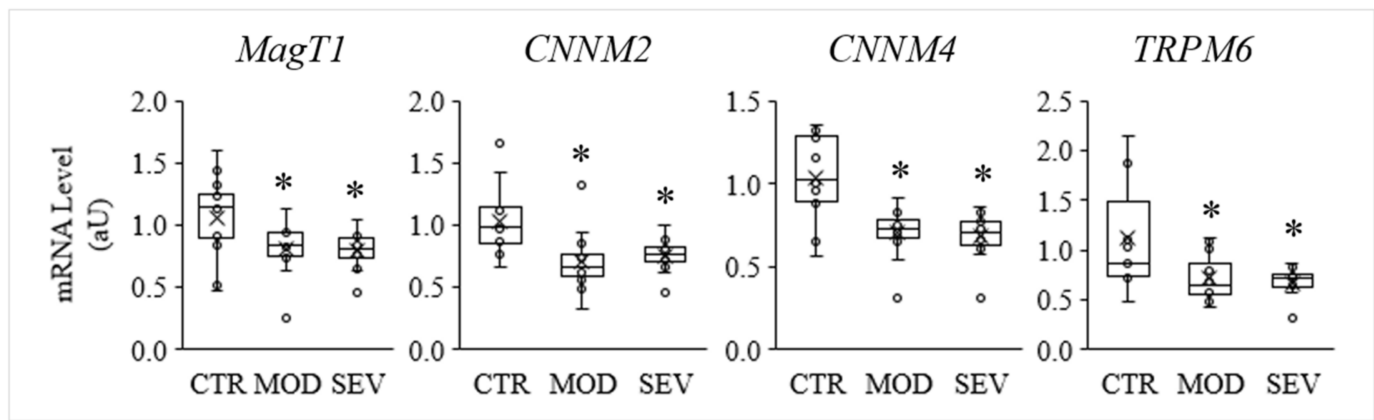

(a)

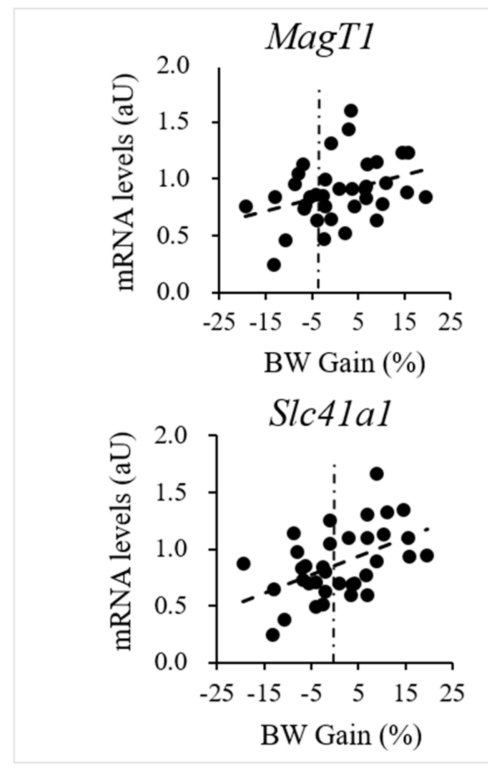

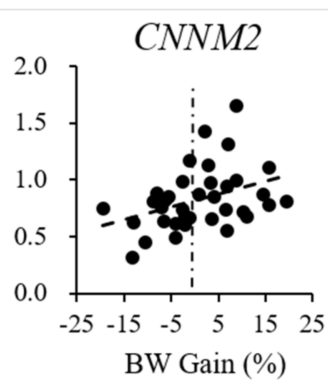

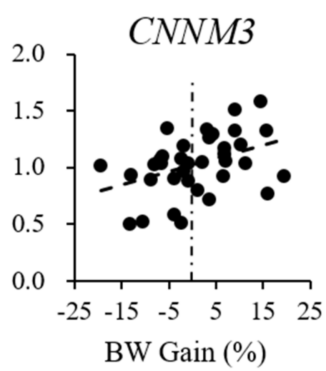

(b)
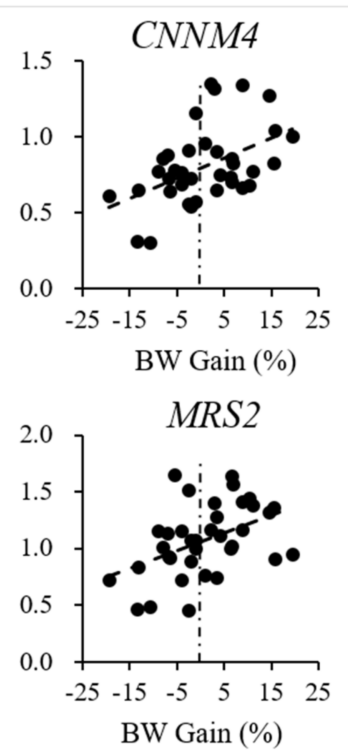

Figure 4. $\mathrm{Mg}^{2+}$-deficient diet and muscle $\mathrm{Mg}^{2+}$ transport and homeostatic systems (MgTHs) mRNA levels. Mice were fed either a control (CTR), a mildly (MOD), or a severely (SEV) $\mathrm{Mg}^{2+}$-deficient diet: (a) gastrocnemius MgTHs mRNA levels; data $(\mathrm{N}=12)$ are presented as box-and-whisker plots; ${ }^{*}$ indicates significant difference $(P<0.05)$ from the CTR group; (b) examples of linear Pearson's regressions between muscle MgTHs mRNA levels and body weight (BW) gain.

\subsection{Mild $\mathrm{Mg}^{2+}$ Deficiency Alters the Expression of Genes Important for Muscle Energy Metabolism and Regeneration}

As $\mathrm{Mg}^{2+}$ is the activator or cofactor of a number of enzymes, modest declines in intramuscular $\mathrm{Mg}^{2+}$ concentrations might modulate biological processes that are critical for muscle physiology. Initially, to assess muscle stress, we evaluated the expression of Trim72, Chac1, and Ddit3. Trim 72 codes for a protein specifically located in the sarcolemma and involved in membrane repair [19]. Chac1 encodes a protein acting downstream of ATF4 implicated in muscle atrophy [20], and Ddit3 encodes a member of the CCAAT/enhancerbinding protein (C/EBP) family of transcription factors and inhibits myogenesis [21]. We found that severely and mildly $\mathrm{Mg}^{2+}$-deficient diets did not modulate Trim72 (Figure 5). Moreover, severe $\mathrm{Mg}^{2+}$ deficiency, but not mild $\mathrm{Mg}^{2+}$ deficiency, upregulated the stress genes Chac1 and Ddit3 (Figure 5).

To reduce the potential interferences due to the activation of the stress response and to mimic chronic latent deficiency conditions, further investigations were focused on mild $\mathrm{Mg}^{2+}$ deficiency. Moreover, TaqMan low-density array (TLDA) analyses revealed that mild $\mathrm{Mg}^{2+}$ deficiency was sufficient to rapidly alter the expression of genes important for lipid and carbohydrate metabolism (Figure 6a). These included Slc2a4 and Slc6a8, coding for Glut4 and creatine transporter (CT)-1, respectively, Gapdh, Cs (citrate synthase), Plin2, 
a marker of intramyocellular lipid droplets, and the transcription factors Creb1, Srebf1, and Srebf2. Mild $\mathrm{Mg}^{2+}$ deficiency also rapidly altered the expression of genes involved in muscle regeneration (Figure 6b), i.e., Myog (myogenin), Mef2c (myocyte enhancer factor 2C), Mstn (myostatin), and its receptors (Acvr2a and Acvr2b).

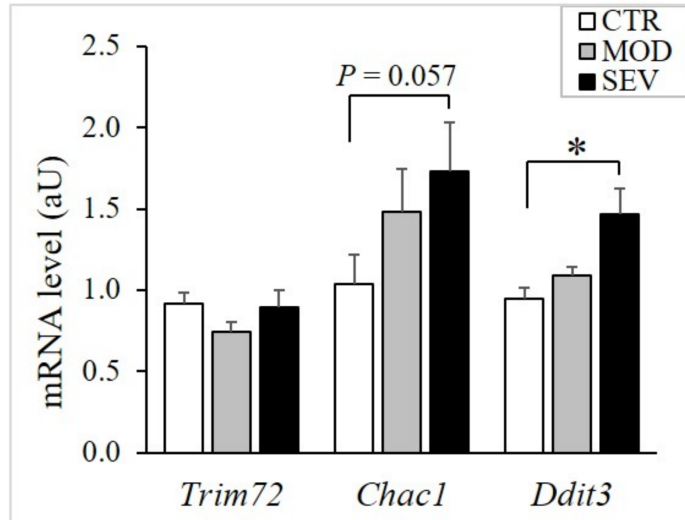

Figure 5. Muscle mRNA levels of stress genes in mice fed $\mathrm{Mg}^{2+}$-deficient diet. TaqMan low-density array (TLDA) was used to measure mRNA levels in gastrocnemius muscle of mice fed either a control (CTR; white bars), a mildly (MOD; grey bars), or a severely $\mathrm{Mg}^{2+}$-deficient diet (SEV; black bars). * indicates significant difference $(P<0.05)$ from the CTR group.

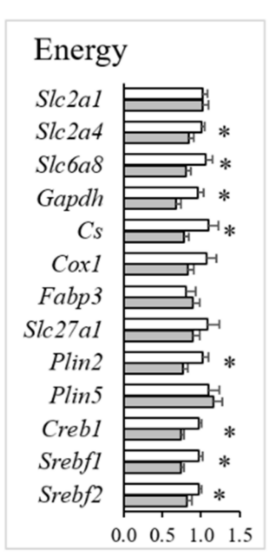

(a)

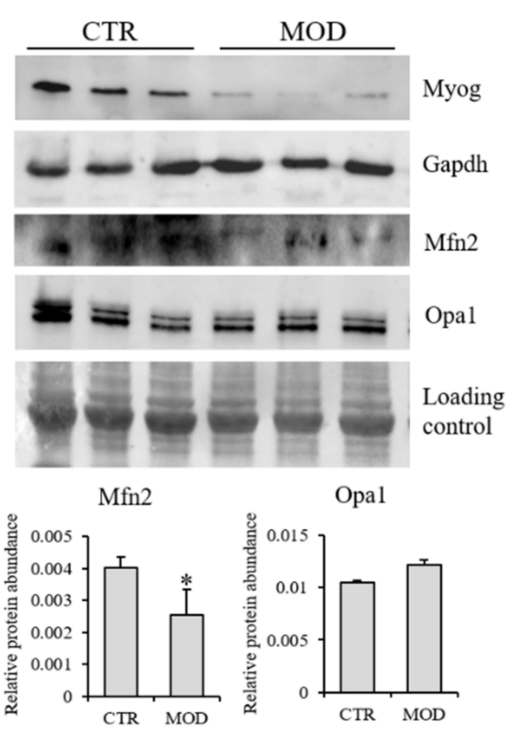

(c)
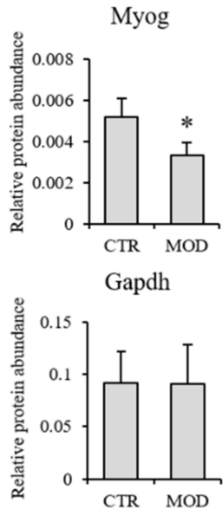

(b)

Figure 6. Muscle mRNA levels of genes involved in energy metabolism (a) and muscle regeneration (b) in mice fed a mildly $\mathrm{Mg}^{2+}$-deficient diet. Results are means $\pm \mathrm{SE}(\mathrm{N}=12)$. White columns CTR, grey columns mild $\mathrm{Mg}^{2+}$ deficiency. (c) Western blot was performed on $40 \mu \mathrm{g}$ of lysates using specific antibodies against Myog, Gapdh, Mfn1, and Opa1. A representative western is shown. Densitometry was performed on three different blots. ${ }^{*}$ indicates significant difference $(P<0.05)$ from the CTR group.

We tested the total amounts of some proteins by Western blot on lysates from gastrocnemius muscles of 12 animals under control or mildly $\mathrm{Mg}^{2+}$-deficient diet. As shown in Figure $6 c$, we found a significant reduction of Myog and no modulation of Gapdh. 


\subsection{Mild $\mathrm{Mg}^{2+}$ Deficiency Alters Expression of Genes Important for Muscle Proteostasis}

Amongst the transduction pathways implicated in the regulation of muscle atrophy [22,23], mild $\mathrm{Mg}^{2+}$ deficiency was associated with a decreased expression of Fbxo32 (MAFbx), Zeb1, Fbxo31, Atf4, and Eif4ebp1, while the mRNA levels of other major regulators, e.g., Trim63 (MuRF1), Foxo3, Mdm2, Fbxo30 (Musa1), Fbxo21 (Smart), Gadd45a, and Cdkn1a (p21) did not significantly change (Figure 7a).

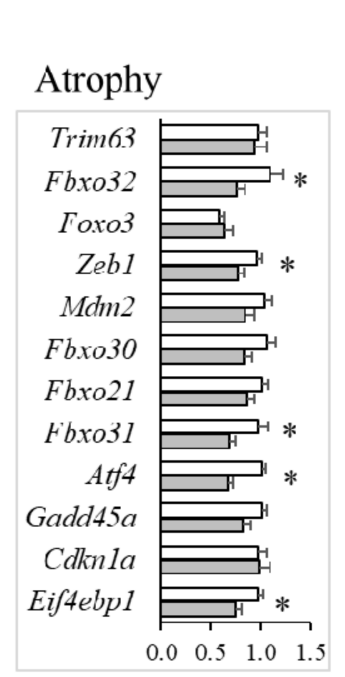

(a)

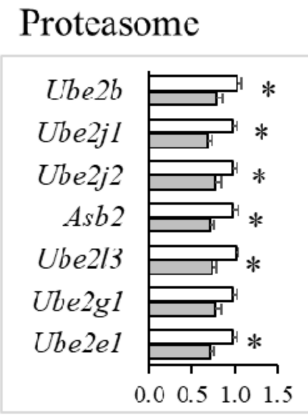

\section{(b)}

\section{Calcium}

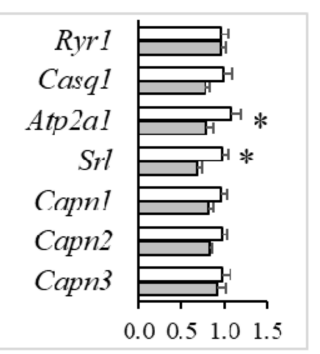

(e)

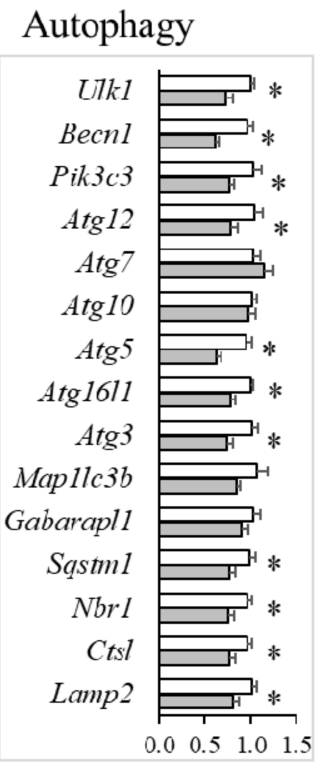

(c)

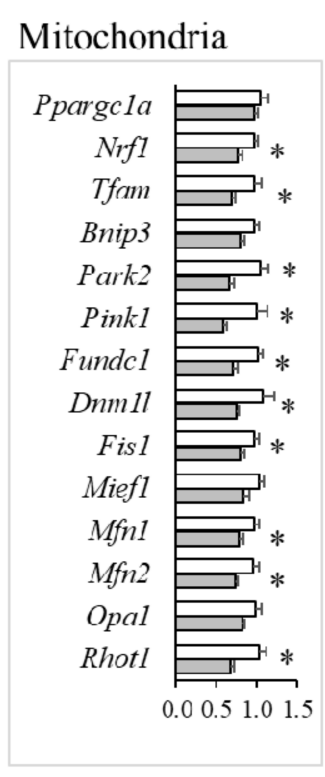

(d)

Figure 7. Muscle gene expression in mice fed a mildly $\mathrm{Mg}^{2+}$-deficient diet. TaqMan low-density array (TLDA) was used to measure mRNA levels of genes critical for muscle physiology of mice fed either a control (white bars) or a mildly (grey bars) $\mathrm{Mg}^{2+}$-deficient diet. Genes involved in muscle atrophy (a), proteostasis $(\mathbf{b})$, autophagy (c), mitochondrial dynamics (d) and calcium homeostasis (e) were analyzed. Results are means $\pm \mathrm{SE}(\mathrm{N}=12) .{ }^{*}$ indicates significant difference $(P<0.05)$ from the CTR group.

In agreement with the downregulation of major atrogenes by mild $\mathrm{Mg}^{2+}$ deficiency, e.g., Fbxo32 (MAFbx), there was also evidence for altered expression of many genes involved in protein catabolism. This encompassed the downregulation of (i) E2-activating genes (Ube2b, Ube2j1, Ube2j2, Asb2, Ube2l3, Ube2e1) of the ubiquitin-proteasome system (Figure 7b); (ii) genes regulating initiation (Ulk1, Becn1, Pik3c3), elongation (Atg12, Atg5, Atg16l1, Atg3), substrate/cargo recruitment (Sqstm1, Nbr1) and lysosomal proteolysis (Ctsl, Lamp2) in autophagy (Figure 7c). However, $\mathrm{Mg}^{2+}$ deficiency did not affect the expression of $\mathrm{Ca}^{2+}$-dependent proteases (Capn1, Capn2, Capn3 calpains) (Figure 7e).

\subsection{Mild $\mathrm{Mg}^{2+}$ Deficiency, Mitochondria, and $\mathrm{Ca}^{2+}$ Homeostasis}

Mitochondria play multifaceted roles in essential aspects of skeletal muscle cell physiology [24]. Our TLDA analyses indicated that a mild $\mathrm{Mg}^{2+}$ deficiency is sufficient to downregulate genes regulating mitophagy (Park2, Pink1, Fundc1) (Figure 7d), in addition to reducing the expression of genes implicated in mitogenesis (Nrf1, Tfam), mitochondrial fission (Dnm1l, Fis1), and fusion (Mfn1, Mfn2, Rhot1) (Figure 7d). By Western blot, we confirmed the downregulation of mitofusin (Mfn)2 (Figure 6c). Opa1, instead, was not modulated, both at the RNA and the protein levels (Figures $6 \mathrm{c}$ and $7 \mathrm{~d}$ ). 
$\mathrm{Mg}^{2+}$ may also modulate $\mathrm{Ca}^{2+}$-permeable channels and $\mathrm{Ca}^{2+}$-binding proteins. $\mathrm{Ca}^{2+}$ handling by the sarcoplasmic reticulum is a key feature in muscle contraction. Action potentials elicit contraction by the release of $\mathrm{Ca}^{2+}$ from the sarcoplasmic reticulum through the ryanodine receptors (Ryr1) that are regulated by calsequestrin-1 (Casq1). For muscle relaxation, $\mathrm{Ca}^{2+}$ is transported back to the sarcoplasmic reticulum by sarco/endoplasmic reticulum $\mathrm{Ca}^{2+}$-ATPases (Serca), regulated by sarcalumenins $(\mathrm{Srl})[25,26]$. It is noteworthy that our TLDA study emphasized that a mild $\mathrm{Mg}^{2+}$ deficiency did not affect the expression of genes involved in contraction (Ryr1, Casq1), while it downregulated the expression of those implicated in relaxation, Atp2a1 (Serca), and Srl (Figure 7e).

\section{Discussion}

Appropriate nutrition is indispensable for normal muscle metabolism and function [7]. In humans, cross-sectional associations between low $\mathrm{Mg}^{2+}$ intake and loss of skeletal mass and function were reported in large population cohorts [27-29].

To get insight into the role of $\mathrm{Mg}^{2+}$ in muscle health, we developed an experimental model in which mice were fed a moderately or severely $\mathrm{Mg}^{2+}$-deficient diet. Both these dietetic regimens significantly reduced serum $\mathrm{Mg}^{2+}$ levels, a useful biomarker of $\mathrm{Mg}^{2+}$ status [6]. Unexpectedly, we did not detect a reduction of erythrocytes $\mathrm{Mg}^{2+}$ concentration, differently from a previous report demonstrating the concomitant reduction of serum and erythrocyte $\mathrm{Mg}^{2}$ in animals fed the severely deficient diet [15]. We have no explanation at the moment for this discrepancy. Interestingly, we found that some $\mathrm{Mg}^{2+}$ transporters were significantly downregulated in the muscle. This finding explains the reduced amounts of intracellular $\mathrm{Mg}^{2+}$ in the muscle and might also represent an initial, adaptive response aimed at maintaining circulating $\mathrm{Mg}^{2+}$ as close to physiological levels as possible. In this perspective, it is noteworthy that 12-13 week-old Trpm6-deficient adult mice are hypomagnesemic and sarcopenic, events reversible upon supplementation with $\mathrm{Mg}^{2+}$ [30]. Additionally, CNNM2+/ - mice were hypomagnesemic, but no data are available on the skeletal muscle yet [31]. In our experimental model, $\mathrm{Mg}^{2+}$ deficiency was associated with a significant decline in body weight gain. Interestingly, regression analysis revealed a positive correlation between body weight gain and the downregulation of MagT1, CNNM2, CNNM3, CNNM4, MRS2, Slc41a1 in the muscle. Indeed, redundancy among members of $\mathrm{Mg}^{2+}$ transporters likely enables functional compensation to maintain sufficient $\mathrm{Mg}^{2+}$ homeostasis resulting in normal body weight.

We found no structural signs of muscle atrophy after 14 days in $\mathrm{Mg}^{2+}$ deficient regimen. This finding might be due to the downregulation of the genes coding for myostatin and its receptors, which activate the ubiquitin-proteasome and autophagy pathways, thus resulting in muscle wasting [32]. Accordingly, TLDA analysis revealed the reduced expression of genes involved in the regulation of the proteasome and autophagy in mice fed a moderately low $\mathrm{Mg}^{2+}$ diet.

By TLDA analysis, we found significant differences in the expression of genes coding for proteins involved in energy metabolisms. Glucose transport into cells is the first step in glucose metabolism. We here describe the downregulation of the gene encoding the glucose transporter Glut4. Interestingly, in the gastrocnemius of type 2 diabetic rats, Glut4 was reduced, and $\mathrm{Mg}^{2+}$ supplementation was sufficient to revert it [33]. The low expression of Glut4 in $\mathrm{Mg}^{2+}$-deficient mice indicates that less glucose might be available for energy production, further impaired by the downregulation of Citrate synthase, involved in the first reaction of the Krebs cycle. Reduced amounts of Plin2, Srebf1, and Srebf2 transcripts might be predictive of altered lipid metabolism. It is noteworthy that Srebf1 and Srebf2 are downregulated in the skeletal muscle of diabetic individuals [34] and that the overexpression of Plin 2 ameliorates insulin sensitivity in skeletal muscle [35]. Additionally, Slc6a8, coding for creatine transporter (CT)-1, is reduced in moderately $\mathrm{Mg}^{2+}$-deficient mice. In the skeletal muscle, the creatine system is fundamental for optimal energy utilization, especially at the beginning of exercise and during intense physical activity, because it serves as a first-line energy buffer that maintains ATP levels constant. CT1 is the major route for 
creatine entry in skeletal muscle cells and has a central role in ensuring high intracellular creatine content [36]. Consistently, CT1-deficient mice feature muscle atrophy, reduced strength, and endurance [37].

TLDA also disclosed the reduced expression of genes involved in mitophagy, fusion, and fission, thus indicating alterations of mitochondrial dynamics that might be accompanied by impaired energy production in $\mathrm{Mg}^{2+}$-deficient mice. Moreover, we found a marked reduction of the total amounts of Mfn2, a GTPase located on the outer mitochondrial membrane which is critical for mitochondrial fusion [38]. It is noteworthy that altered mitochondria have been implicated in sarcopenia in the elderly, in muscle atrophy associated with disuse, in muscular dystrophies, and in insulin resistance [24]. TLDA also shows the downregulation of genes that coordinate the different steps of autophagy in $\mathrm{Mg}^{2+}$-deficient mice. This result is in agreement with data from cultured cells. Indeed, both TRPM7 or MagT1 silencing and $\mathrm{Mg}^{2+}$ deficiency activate autophagy in human mesenchymal stem cells induced osteogenic differentiation [39]. Consistently, high concentrations of extracellular $\mathrm{Mg}^{2+}$ inhibit autophagy in chondrocyte ATDC5 cells [40].

Our study presents some limitations. First of all, the experiments were performed using young growing animals. It will be relevant to extend our studies using animals of different ages and to evaluate metabolic parameters related to glucose metabolism and lipid metabolism to obtain a complete overview of the fundamental function exerted by skeletal muscle. We also highlight that our study was performed on male mice. To identify potential gender-related differences, the same experiments should be performed on females. Another limitation is that only some proteins were evaluated. Further experiments are required to confirm the altered expressions at the protein level and/or their functional activity.

\section{Conclusions}

Our results emphasize that even a mild $\mathrm{Mg}^{2+}$ deficiency, as found in the Western population, is sufficient to modulate the gene expression of major pathways, mostly related to energy metabolism, proteostasis, autophagy, and mitochondrial dynamics in the skeletal muscle. Consequently, supplementing $\mathrm{Mg}^{2+}$ in $\mathrm{Mg}^{2+}$-deficient individuals might be a simple and costless countermeasure to maintain healthy muscles and metabolic balance.

Author Contributions: Conceptualization, A.M., D.B. (Daniel Béchet), and J.A.M.; data curation, D.B. (Dominique Bayle), A.M., and D.B. (Daniel Béchet); formal analysis, D.B. (Dominique Bayle), C.C.-G., M.Z., and M.M.-Z.; funding acquisition, S.C. and D.B. (Daniel Béchet); investigation, D.B. (Dominique Bayle) and C.C.-G.; Methodology, D.B. (Dominique Bayle), C.C.-G., M.G., S.C., M.Z., A.P.-S., and D.B. (Daniel Béchet); project administration, A.M., D.B. (Daniel Béchet), and J.A.M.; supervision, A.M., D.B. (Daniel Béchet), and J.A.M.; validation, S.C., A.M., D.B. (Daniel Béchet), and J.A.M.; writing — original draft preparation, D.B. (Daniel Béchet); writing-review and editing, A.M., D.B. (Daniel Béchet), and J.A.M. All authors have read and agreed to the published version of the manuscript.

Funding: This research was funded by the French government's IDEX-ISITE initiative 16-IDEX-0001 (CAP 20-25) and, in part, by Università di Milano (Fondi del Piano di Sviluppo di Ricerca 2020).

Institutional Review Board Statement: The study was conducted according to the guidelines of the Declaration of Helsinki and approved by the Ethics Committee C2EA-02 of INRAE (Protocol Code 14025-201803121538803 of 25 April 2018).

Data Availability Statement: The data presented in this study are openly available in INRA Dataverse at https:/ / data.inrae.fr/dataset.xhtml?persistentId=doi:10.15454/IVBODD (accessed on 24 June 2021).

Acknowledgments: Acknowledgements to the animal facility staff in charge of the experimental protocol and to Séverine Valero for the technical assistance and plasma magnesium analysis. The authors acknowledge support from the University of Milan through the APC initiative.

Conflicts of Interest: The authors declare no conflict of interest. 


\section{References}

1. Cazzola, R.; Della Porta, M.; Manoni, M.; Iotti, S.; Pinotti, L.; Maier, J.A. Going to the roots of reduced magnesium dietary intake: A tradeoff between climate changes and sources. Heliyon 2020, 6, e05390. [CrossRef] [PubMed]

2. Lo Piano, F.; Corsonello, A.; Corica, F. Magnesium and elderly patient: The explored paths and the ones to be explored: A review. Magnes. Res. 2019, 32, 1-15. [CrossRef] [PubMed]

3. Kisters, K.; Gröber, U. Magnesium and thiazide diuretics. Magnes. Res. 2018, 31, 143-145. [CrossRef]

4. Hansen, B.A.; Bruserud, Ø. Hypomagnesemia in critically ill patients. J. Intensive Care 2018, 6, 1-11. [CrossRef]

5. Arnaud, M.J. Update on the assessment of magnesium status. Br. J. Nutr. 2008, 99, S24-S36. [CrossRef]

6. Witkowski, M.; Hubert, J.; Mazur, A. Methods of assessment of magnesium status in humans: A systematic review. Magnes. Res. 2011, 24, 163-180. [CrossRef]

7. de Baaij, J.H.F.; Hoenderop, J.G.J.; Bindels, R.J.M. Magnesium in Man: Implications for Health and Disease. Physiol. Rev. 2015, 95, 1-46. [CrossRef] [PubMed]

8. Giménez-Mascarell, P.; González-Recio, I.; Fernández-Rodríguez, C.; Oyenarte, I.; Müller, D.; Martínez-Chantar, M.L.; MartínezCruz, L.A. Current Structural Knowledge on the CNNM Family of Magnesium Transport Mediators. Int. J. Mol. Sci. 2019, 20, 1135. [CrossRef] [PubMed]

9. Kolisek, M.; Sponder, G.; Pilchova, I.; Cibulka, M.; Tatarkova, Z.; Werner, T.; Racay, P. Magnesium Extravaganza: A Critical Compendium of Current Research into Cellular $\mathrm{Mg}(2+)$ Transporters Other than TRPM6/7. Rev. Physiol. Biochem. Pharmacol. 2019, 176, 65-105. [CrossRef] [PubMed]

10. Carvil, P.; Cronin, J. Magnesium and implications on muscle function. Strength Cond. J. 2010, 32, 48-54. [CrossRef]

11. Coudy-Gandilhon, C.; Gueugneau, M.; Taillandier, D.; Combaret, L.; Polge, C.; Roche, F.; Barthélémy, J.-C.; Féasson, L.; Maier, J.A.; Mazur, A.; et al. Magnesium transport and homeostasis-related gene expression in skeletal muscle of young and old adults: Analysis of the transcriptomic data from the PROOF cohort Study. Magnes. Res. 2019, 32, 72-82. [CrossRef] [PubMed]

12. Gueugneau, M.; Coudy-Gandilhon, C.; Théron, L.; Meunier, B.; Barboiron, C.; Combaret, L.; Taillandier, D.; Polge, C.; Attaix, D.; Picard, B.; et al. Skeletal muscle lipid content and oxidative activity in relation to muscle fiber type in aging and metabolic syndrome. J. Gerontol. A Biol. Sci. Med. Sci. 2015, 70, 566-576. [CrossRef]

13. Gueugneau, M.; Coudy-Gandilhon, C.; Meunier, B.; Combaret, L.; Taillandier, D.; Polge, C.; Attaix, D.; Roche, F.; Féasson, L.; Barthélémy, J.-C.; et al. Lower skeletal muscle capillarization in hypertensive elderly men. Exp. Gerontol. 2016, 76, 80-88. [CrossRef] [PubMed]

14. Storey, J.D.; Tibshirani, R. Statistical significance for genomewide studies. Proc. Natl. Acad. Sci. USA 2003, 100, 9440-9445. [CrossRef] [PubMed]

15. Rondón, L.J.; Groenestege, W.M.T.; Rayssiguier, Y.; Mazur, A. Relationship between low magnesium status and TRPM6 expression in the kidney and large intestine. Am. J. Physiol. Regul. Integr. Comp. Physiol. 2008, 294, R2001-R2007. [CrossRef] [PubMed]

16. Ryazanova, L.V.; Rondon, L.J.; Zierler, S.; Hu, Z.; Galli, J.; Yamaguchi, T.P.; Mazur, A.; Fleig, A.; Ryazanov, A.G. TRPM7 is essential for $\mathrm{Mg}(2+)$ homeostasis in mammals. Nat. Commun. 2010, 1, 109. [CrossRef] [PubMed]

17. Li, F.Y.; Chaigne-Delalande, B.; Kanellopoulou, C.; Davis, J.C.; Matthews, H.F.; Douek, D.C.; Cohen, J.I.; Uzel, G.; Su, H.C.; Lenardo, M.J. Second messenger role for Mg2+ revealed by human T-cell immunodeficiency. Nature 2011, 475, 471-476. [CrossRef]

18. Blommaert, E.; Péanne, R.; Cherepanova, N.A.; Rymen, D.; Staels, F.; Jaeken, J.; Race, V.; Keldermans, L.; Souche, E.; Corveleyn, A.; et al. Mutations in MAGT1 lead to a glycosylation disorder with a variable phenotype. Proc. Natl. Acad. Sci. USA 2019, 116, 9865-9870. [CrossRef] [PubMed]

19. Cai, C.; Masumiya, H.; Weisleder, N.; Matsuda, N.; Nishi, M.; Hwang, M.; Ko, J.-K.; Lin, P.; Thornton, A.; Zhao, X.; et al. MG53 nucleates assembly of cell membrane repair machinery. Nat. Cell Biol. 2009, 11, 56-64. [CrossRef] [PubMed]

20. Ebert, S.M.; Bullard, S.A.; Basisty, N.; Marcotte, G.R.; Skopec, Z.P.; Dierdorff, J.M.; Al-Zougbi, A.; Tomcheck, K.C.; DeLau, A.D.; Rathmacher, J.A.; et al. Activating transcription factor 4 (ATF4) promotes skeletal muscle atrophy by forming a heterodimer with the transcriptional regulator C/EBP $\beta$. J. Biol. Chem. 2020, 295, 2787-2803. [CrossRef]

21. AlSudais, H.; Lala-Tabbert, N.; Wiper-Bergeron, N. CCAAT/Enhancer Binding Protein $\beta$ inhibits myogenic differentiation via ID3. Sci. Rep. 2018, 8, 16613. [CrossRef]

22. Ebert, S.M.; Al-Zougbi, A.; Bodine, S.C.; Adams, C.M. Skeletal Muscle Atrophy: Discovery of Mechanisms and Potential Therapies. Physiology 2019, 34, 232-239. [CrossRef] [PubMed]

23. Larsson, L.; Degens, H.; Li, M.; Salviati, L.; Lee, Y., II; Thompson, W.; Kirkland, J.L.; Sandri, M. Sarcopenia: Aging-Related Loss of Muscle Mass and Function. Physiol. Rev. 2019, 99, 427-511. [CrossRef] [PubMed]

24. Gouspillou, G.; Hepple, R.T. Editorial: Mitochondria in Skeletal Muscle Health, Aging and Diseases. Front. Physiol. 2016, 7, 446. [CrossRef]

25. Leberer, E.; Timms, B.G.; Campbell, K.P.; MacLennan, D.H. Purification, calcium binding properties, and ultrastructural localization of the 53,000- and 160,000 (sarcalumenin)-dalton glycoproteins of the sarcoplasmic reticulum. J. Biol. Chem. 1990, 265, 10118-10124. [CrossRef]

26. Gueugneau, M.; Coudy-Gandilhon, C.; Gourbeyre, O.; Chambon, C.; Combaret, L.; Polge, C.; Taillandier, D.; Attaix, D.; Friguet, B.; Maier, A.B.; et al. Proteomics of muscle chronological ageing in post-menopausal women. BMC Genom. 2014, 15, 1165. [CrossRef] [PubMed] 
27. Petermann-Rocha, F.; Chen, M.; Gray, S.R.; Ho, F.K.; Pell, J.P.; Celis-Morales, C. Factors associated with sarcopenia: A crosssectional analysis using UK Biobank. Maturitas 2020, 133, 60-67. [CrossRef] [PubMed]

28. Ter Borg, S.; de Groot, L.C.P.G.M.; Mijnarends, D.M.; de Vries, J.H.M.; Verlaan, S.; Meijboom, S.; Luiking, Y.C.; Schols, J.M.G.A. Differences in Nutrient Intake and Biochemical Nutrient Status Between Sarcopenic and Nonsarcopenic Older Adults-Results From the Maastricht Sarcopenia Study. J. Am. Med. Dir. Assoc. 2016, 17, 393-401. [CrossRef]

29. Orsso, C.E.; Tibaes, J.R.B.; Oliveira, C.L.P.; Rubin, D.A.; Field, C.J.; Heymsfield, S.B.; Prado, C.M.; Haqq, A.M. Low muscle mass and strength in pediatrics patients: Why should we care? Clin. Nutr. 2019, 38, 2002-2015. [CrossRef]

30. Chubanov, V.; Ferioli, S.; Wisnowsky, A.; Simmons, D.G.; Leitzinger, C.; Einer, C.; Jonas, W.; Shymkiv, Y.; Bartsch, H.; Braun, A.; et al. Epithelial magnesium transport by TRPM6 is essential for prenatal development and adult survival. Elife 2016, 5. [CrossRef]

31. Franken, G.A.C.; Seker, M.; Bos, C.; Siemons, L.A.H.; van der Eerden, B.C.J.; Christ, A.; Hoenderop, J.G.J.; Bindels, R.J.M.; Müller, D.; Breiderhoff, T.; et al. Cyclin M2 (CNNM2) knockout mice show mild hypomagnesaemia and developmental defects. Sci. Rep. 2021, 11, 1-12. [CrossRef] [PubMed]

32. Milan, G.; Romanello, V.; Pescatore, F.; Armani, A.; Paik, J.H.; Frasson, L.; Seydel, A.; Zhao, J.; Abraham, R.; Goldberg, A.L.; et al. Regulation of autophagy and the ubiquitin-proteasome system by the FoxO transcriptional network during muscle atrophy. Nat. Commun. 2015, 6, 1-14. [CrossRef]

33. Morakinyo, A.O.; Samuel, T.A.; Adekunbi, D.A. Magnesium upregulates insulin receptor and glucose transporter-4 in streptozotocin-nicotinamide-induced type-2 diabetic rats. Endocr. Regul. 2018, 52, 6-16. [CrossRef] [PubMed]

34. Sewter, C.; Berger, D.; Considine, R.V.; Medina, G.; Rochford, J.; Ciaraldi, T.; Henry, R.; Dohm, L.; Flier, J.S.; O’Rahilly, S.; et al. Human obesity and type 2 diabetes are associated with alterations in SREBP1 isoform expression that are reproduced ex vivo by tumor necrosis factor-alpha. Diabetes 2002, 51, 1035-1041. [CrossRef]

35. Bosma, M.; Hesselink, M.K.C.; Sparks, L.M.; Timmers, S.; Ferraz, M.J.; Mattijssen, F.; van Beurden, D.; Schaart, G.; de Baets, M.H.; Verheyen, F.K.; et al. Perilipin 2 improves insulin sensitivity in skeletal muscle despite elevated intramuscular lipid levels. Diabetes 2012, 61, 2679-2690. [CrossRef] [PubMed]

36. Brault, J.J.; Abraham, K.A.; Terjung, R.L. Muscle creatine uptake and creatine transporter expression in response to creatine supplementation and depletion. J. Appl. Physiol. 2003, 94, 2173-2180. [CrossRef]

37. Stockebrand, M.; Sasani, A.; Das, D.; Hornig, S.; Hermans-Borgmeyer, I.; Lake, H.A.; Isbrandt, D.; Lygate, C.A.; Heerschap, A.; Neu, A.; et al. A Mouse Model of Creatine Transporter Deficiency Reveals Impaired Motor Function and Muscle Energy Metabolism. Front. Physiol. 2018, 9, 773. [CrossRef]

38. Filadi, R.; Pendin, D.; Pizzo, P. Mitofusin 2: From functions to disease. Cell Death Dis. 2018, 9, 1-13. [CrossRef] [PubMed]

39. Castiglioni, S.; Romeo, V.; Locatelli, L.; Cazzaniga, A.; Maier, J.A.M. TRPM7 and MagT1 in the osteogenic differentiation of human mesenchymal stem cells in vitro. Sci. Rep. 2018, 8, 1-10. [CrossRef]

40. Yue, J.; Jin, S.; Gu, S.; Sun, R.; Liang, Q. High concentration magnesium inhibits extracellular matrix calcification and protects articular cartilage via Erk/autophagy pathway. J. Cell. Physiol. 2019, 234, 23190-23201. [CrossRef] 